which would depress a healthy circulation, give much relief to veins highly distended with water-laden blood. The following case is to the point :-

T. $P-$, aged seventy-three, came to me at the West London Hospital as an out-patient in August last. He was a spare little man, with a dilated heart, in which there was little hypertrophy, with ascites, odema up to the knees, and an irregular pulse. He was passing very little water. By the kindness of my senior, Dr. Thorowgood, he was admitted into the hospital, to be under my care. While giving him digitalis and iron, it seemed very desirable to relieve the circulation. This might be effected by either diaphoresis or catharsis. I preferred the latter, and gave two scruples of compound jalap powder every alternate morning. The relief afforded by this plan was very pronounced: the secretion of urine was much increased, the respiration was easier, and the pulse less irregular and better sustained. After eight different purgings he was so much better, and the ascites and oedema so much relieved, that the purging was abandoned, and the digitalis and iron continued. In a short time he became an out-patient, and walks back wards and forwards from Barnes to Hammersmith weekly, without discomfort; in fact, he is proud to say in how short a time he can accomplish his walk without any shortness of breath or sense of fatigue.

This case shows better than any amount of comment the effects of well-directed catharsis in the venous congestion of heart disease. I may add that in repeated cases experience has taught me the value of catharsis in the treatment of cardiac dropsy.

(To be continued.)

\section{DANGERS OF FENCING : SINGULAR ESCAPE.}

\section{BI THOMAS DANE, M.R.C.S.}

Seramant-Major S-, Staff Instructor of Gymnastics, was fencing with foils on the 30th of April last. His adversary made a strong lunge at him; his foil struck S- on the right breast, bent upwards, and broke about three inches below the button, and the broken point of the remainder of the foil, the jagged end of which is shown in the woodcut, passed on into and through $\mathrm{S}$-_'s neck,

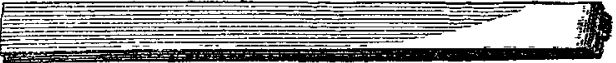

pushing up the skin at the back of the neck, which rapidly formed a tumour there. He felt very little pain, thought it was merely a skin wound in front, but felt as though somebody else had given hin a much harder blow behind. His adversary had withdrawn his foil, and recovered his guard as usual, without knowing that he had even scratched him. S- walked into the dressing-room, showing no sign of faintness and not bleeding much. Finding there was no arterial hamorrhage, I made gentle pressure with the finger for a short time till the bleeding ceased, when I sponged the wound, a ragged one, about three-quarters of an inch long, and brought the edges together with stickingplaster, directed him to keep his head as quiet as possible, and not to bend or twist his neck. In half an hour from the time of receiving the accident there was a tumour at the back of the neck an inch in diameter, and projecting from a quarter to half an inch, probably caused by effusion of blood into the connective tissue under the skin, where it was torn by the end of the foil, which had forced the skin outwards without transfixing it. He progressed quite well. The wound in front healed by first intention. He had for two or three days a little stiffness in the neck; had no difficulty or pain in swallowing or breathing, no numbness either in neck or arm. I discontinued the sticking-plaster on May 6 th, the wound being firmly united.

State on May 8th, when Mr. Nunn kindly examined him with me:-In the front of the neck there was the cicatrix of the wound, one inch from the median line, on the right side, about the level of the upper border of the thyroid cartilage. At the back of the neck, half an inch from the median line, on the same side, and two inches and a quarter above the spine of the seventh cervical vertebra, was a round swelling evidently produced by penetration of the foil almost to the extent of transfixion-that is to say, through the muscles up to the inner surface of the skin. There was some yellow discolouration in patches about the neck, not descending below the line of the clavicle. There was a little tenderness to pressure on the tumour at the back of the neck. There was no pain, numbness, or inconvenience anywhere else, nor were they producible by any movement.

Finchley.road, South Hampstead, N.W.

\section{A dettitrot}

\section{H OSPITAL PRA C T CE, BRITISH AND FOREIGN.}

Nulla autem est alia pro certo noscendi via, nisi quamplurimas et morborum et dissectionum historias, tum aliorum, tum proprias collectas habere, et inter se comparare.-MongagNI De Sed, et Caur. Morb., lib.iv. Procmium.

\section{ST. MARY'S HOSPITAL.}

CASE OF TRAUMATIC TETANUS, TREATED SUCCESSFULLY. (Under the care of Mr. Spencer Smith.)

For the notes of the following case we are indebted to Mr. W. V. Lindsay, house-surgeon.

William W-, aged twenty-seven, married, a joiner, was admitted at 9 P.M. on Nov. 9th, 1874. He stated that, fifteen days before, he trod on a nail, which ran into the ball of his great toe to the depth of half or three-quarters of an inch. He removed the whole of the nail at the time. As the toe was painful, he applied to the infirmary for relief, and was directed to bathe the part with hot water and to poultice it. After two or three days the toe and foot became more painful. On Nov. 5th he felt a pain in the back between the shoulders, which he described as similar to the pain of lumbago, to which affection he was subject; and at the same time his friends noticed that he had a peculiar smile. On the morning of Nov. 8th he felt an aching pain in the jaws along the back teeth, and he found that he cculd not open his mouth wide. On the following day the pain in the back and the pain and stiffness of the jaws were worse.

His condition on admission was as follows:-He could open his mouth to the extent of an inch between the edges of the incisor teeth, and he complained of pain between the shoulders as if a knife were being stuck in. This pain left him for a few minutes at a time during the course of the day. He had no pain in the jaws when he was taken into the hospital, unless he tried to eat anything. He was perspiring freely and felt hot. He had taken only some sago in the way of nourishment. Tongue clean; bowels last opened yesterday morning; pulse 100 ; temperature $996^{\circ}$. He had a small punctured wound on the ball of the great toe of the left foot. There was no redness anywhere, and no pain, except just at the wound when it was touched. He was ordered ten grains of chloral hydrate with ten grains of bromide of potassium every four hours, and beef-tea and milk.

Nov. 10th.-Slept well last night; is in much the same condition as yesterda.y. On introducing a probe into the wound, to clear out some of the linseed of the poultice, the patient complained of great pain in the back, which lasted about a minute. Pulse 82 ; temperature $99 \cdot 9^{\circ}$. The chloral hydrate increased to fifteen grains every four hours. As his bowels had not been open since admission, he was ordered fifteen grains of calomel and jalap powder, to be followed in four hours by an ounce and a half of "house mixture."

11th. - Had a restless night, and complained of pain across the abdomen. Last evening, at 9 P.M., he had an attact of opisthotonos, lasting about three minutes, his head and neck being thrown back. During this time the pain in the back was very severe. He had two more attacks of the same kind this morning. He complained this morning of severe pain in the back and abdomen. The abdominal muscles were quite rigid; he could open his jaws about one 